\title{
MENGEMBANGKAN KEMAMPUAN PEMAHAMAN KONSEP MATEMATIKA DISKRIT DAN PEMBENTUKAN KARAKTER KONSTRUKTIVIS MAHASISWA MELALUI PENGEMBANGAN BAHAN AJAR BERBANTUAN APLIKASI EDUCATION EDMODO BERMODELKAN PROGRESIF PACE
}

\author{
Jajo Firman Raharjo ${ }^{1}$, Herri Sulaiman ${ }^{2}$ \\ ${ }^{1,2}$ Prodi Pendidikan Matematika, FKIP, Universitas Swadaya Gunung Djati Cirebon \\ E-mail :jajofirmanraharjo@gmail.com
}

\begin{abstract}
ABSTRAK
Pembelajaran adalah pengupayaan perbaikan mutu pendidikan yang sudah seharusnya merupakan suatu proses yang mengatisipasi dalam pendidikan masa depan yang bersifat progresif. Perkembangan yang pesat dibidang teknologi informasi dan komunikasi dewasa ini dilandasi oleh perkembangan matematika dibidang teori bilangan, aljabar, teori peluang dan matematika diskrit yang berjalan beriringan dengan kemajuan ilmu pengetahuan dan teknologi dalam era learning society atau masyarakat pembelajar.Banyak kritikan dengan cara dosen yang menyampaikan konsep hanya secara informatif belaka dan mahasiswa hanya dibebani dengan tugas latihan yang banyak tanpa pemahaman yang bermakna. Di lain pihak, penyajian materi pada bahan ajar perkuliahan belum sepenuhnya efektif dan komprehensif memberikan akses mahasiswa untuk berkembang secara mandiri melalui pemahaman konsep. Standar pencapaian kemampuan pemahaman sangat mungkin tercapai dengan mengembangkan bahan ajar dengan aplikasi adaptive e-learning melalui aplikasi Edmodo dengan model Progresif PACE (Project, Avtivity, Cooperative learning, Exercise) karena dengan edmodo model progresif PACE, mahasiswa mampu mengkonstruksi sendiri ide matematis melalui kegiatan ilmiah sehingga karakter konstruktivispun terbentuk.Penelitian ini adalah penelitian pengembangan menggunakan 4$\mathrm{D}$ Thiagarajan yaitu define, design, develop dan dessiminate untuk mengembangkan bahan ajar aplikasi Edmodo dengan model Progresif PACE yang baik pada pencapaian kemampuan pemahaman konsep dan pembentukan karakter konstruktivis mahasiswa. Tujuan penelitian ini adalah menghasilkan bahan ajar yang dapat memotivasi dosen untuk menggunakannya sebagai variasi pembelajaran yang inovatif dan progresif. Implementasi bahan ajar yang berkontribusi kepada mahasiswa untuk mampu menemukan kemampuan pemahaman konsep secara konstruktivis. Hasil Penelitian ini menunjukan bahwa buku ajar yang dikembangkan menggunakan model Progresif PACE dalam mengembangkan kemampuan pemahaman konsep matematis pada mata kuliah matematika diskrit berbantuan aplikasi Education Edmodo adalah berkriteria baik yaitu 1) Ketuntasan pembelajaran menggunakan model Progresif PACE dalam mengembangkan kemampuan pemahaman konsep matematis pada mata kuliah matematika diskrit berbantuan aplikasi Education Edmodo, 2) Buku ajar yang dikembangkan efektif dan 3) Buku ajar yang dikembangkan dengan pembelajaran menggunakan model ProgresifPACE praktis; serta, 4) Pembelajaran menggunakan model Progresif PACE dalam mengembangkan kemampuan pemahaman konsep matematis pada mata kuliah matematika diskrit berbantuan aplikasi Education Edmodo berpengaruh terhadap pembentukan karakter konstruktivis mahasiswa.
\end{abstract}

Kata Kunci :Pengembangan Buku ajar, Aplikasi Edmodo model Progresif PACE, pemahaman konsep dan Karakter konstruktivis. 


\section{PENDAHULUAN}

Pembelajaran adalah suatu pengupayaan perbaikan kualitas mutu pendidikan yang sudah seharusnya merupakan suatu proses mengatisipasi. Begitupula dengan tantangan pembelajaran matematika pada pendidikan tinggi yang sudah seharusnya adalah sebagai antisipasi menyiapkan kualitas mahasiswa yang siap bersaing dengan perubahan, memiliki kemampuan matematis tidak hanya berorientasi pada penguasaan pengetahuan tetapi juga kemampuan mahasiswa dalam mengembangkan kecakapan kognitifnya, kecakapan interpersonalnyadan juga kecakapan dalam bekerjasama, yang tentunya akan sangat dibutuhkan dalam memecahkan persoalan dalam kehidupan jangka panjang. Perkembangan yang pesat dibidang teknologi informasi dan komunikasi dewasa ini dilandasi oleh perkembangan matematika dibidang teori bilangan, aljabar, teori peluang maupun matematika diskrit yang berjalan beriringan dengan kemajuan ilmu pengetahuan dan teknologi dalam era learning society atau masyarakat pembelajar.

Dalam memahami konsep matematika diskrit menggunakan Education Edmodo, akan sangat optimal apabila Education Edmododikembangan dengan pembelajaran adaftif sesuai kebutuhan mahasiswa. Pengembangan bahan ajar dengan aplikasi Education Edmodoberbasis PACE adalah bahan ajar yang dikembangkan dengan Edmodo yang bercirikan Proyek (Project), Aktivitas (Activity), Pembelajaran kooperatif (Cooperative Learning) dan Latihan (Exercise), berorientasi pada mahasiswa, memberikan akses kepada mahasiswa untuk mengembangkan kemampuan secara mandiri, mengembangkan kecakapan interpersonal dan sikap kerjasama yang tidak semata-mata hanya menekankan pada kompetensi tetapi juga kreatifitas dalam mencapai kemampuan pemahaman konsep dalam matematika diskrit. Dengan demikian dapat disimpulkan bahwa untuk mencapai kemampuan pemahaman konsep matematika diskrit guna mendukung optimalisasi pendidikan tidak terlepas dari peran perkembangan teknologi informasi dan komunikasi melaui e-learning dengan mengembangkan buku ajar dengan aplikasi Edmodo yang dikembangkan dengan melalui model Progresif PACE sehingga terbentuk karakter konstruktivis mahasiswa yang siap mengatasi segala macam perubahan menuju tercapainya pembelajaran matematika yang bermutu dan pengupayaan pendidikan dimasa depan. Menurut (Sulthon, 2013: 141) ciri-ciri atau karakter konstruktivistik dapat diperhatikan melalui adanya kerjasama, saling menunjang, menyenangkan atau tidak membosankan, belajar dengan bergairah, pembelajaran terintegrasi, menggunakan berbagai sumber, siswa aktif, berbagi dengan teman, siswa kritis dan guru kreatif, serta adanya laporan kepada orangtua mahasiswa berupa portofolio.

Adapun permasalahan dalam penelitian ini adalah bagaimanakah pengembangan buku ajar matematika diskrit yang valid, praktis dan efektif dalam mencapai kemampuan pemahaman konsep matematis pada mata kuliah matematika diskrit dengan model Progresif PACE berbantuan aplikasi Education Edmodo.

Berdasarkan masalah penelitian yang telah dirumuskan di atas, maka tujuan utama penelitian ini adalah untuk menghasilkan bahan ajar yang dikembangan dengan berbantuan aplikasi Education Edmodo dengan model E-Learning PACE terhadap pencapaian kemampuan pemahaman konsep dan pembentukan karakter konstruktivis 
mahasiswapada kajian mata kuliah merupakan unsur pentingdalam matematika diskrit yang baik.

mempertahankan konsep-konsep baru, serta (3) mengutamakan pembelajaran aktif

DESAIN PENELITIAN PENGEMBANGAN MODEL 4D THIAGARAJAN

Dalam pengembangan sistem pembelajaran disini digunakan model pengembangan Thiagarajan. Thiagarajan membagi pengembangan perangkat pembelajaran atas empat tahap yang dikenal dengan sebutan 4-D (Four-D model), yaitu tahap pendefinisian (define), tahap perancangan (design), tahap pengembangan (develop), dan pendesiminasian (deseminate) (Thiagarajan, 1974). Namun pada penelitian ini tahap penelitian pengembangan model 4D dimodifikasi hanya sampai tahap develop. Tahap deseminat tidak dilakukan karena keterbatasan waktu dan ruang penyebaran, namun kepraktisan buku ajar tetap diteliti dengan asumsi bahwa penyebaran terbatas dapat dilakukan dalam penelitian ini untuk mengetahui kepraktisan buku ajar.

\section{PEMBELAJARAN DENGAN APLIKASI ONLINE EDUCATION EDMODO DENGAN MODEL PROGRESIF PACE}

Salah satu model yang menganut teori belajar konstruktivisme yang menekankan keterlibatanaktif mahasiswa adalah pembelajaran Model PACE. Model PACE dikembangkan oleh Lee(1999) yang merupakan singkatan dari Proyek (Project), Aktivitas (Activity), Pembelajarankooperatif (Cooperative Learning) dan Latihan (Exercise). Mahasiswa yang diajarkan olehModel PACE jauh lebih terlibat dalam pembelajaran aktif melalui kerja kelompok dan diskusi kelas.Model PACE didasarkan pada prinsip-prinsip: (1) mengutamakan pengkonstruksianpengetahuan sendiri melalui bimbingan, (2) praktik dan umpan balik dalammemecahkan suatu masalah (Lee, 1999).

Pembelajaran dengan Aplikasi Online

Education Edmodo dengan model Progresif

$P A C E$ adalah pembelajaran yang terdiri atas kegiatan Proyek (Project), Aktivitas (Activity), Pembelajaran kooperatif (Cooperative Learning) dan Latihan (Exercise), berorientasi pada mahasiswa, memberikan akses kepada mahasiswa untuk mengembangkan kemampuan secara mandiri, mengembangkan kecakapan interpersonal dan sikap kerjasama yang tidak semata-mata hanya menekankan pada kompetensi tetapi juga kreatifitas yang secara progresif mencapai kemampuan pemahaman konsep dalam matematika diskrit dalam kelas virtual menggunakan aplikasi Edmodo yaitu aplikasi pendidikan jejaring sosial pribadi bagi guru dan siswa dengan platform sosial yang aman dengan model kicauan seperti situs jejaring sosial pada umumnya, Edmodo dapat menjadikan jaringan khusus bagi guru dan siswa untuk berbagi ide, berkas, peristiwa, dan tugas.

\section{KEMAMPUAN PEMAHAMAN KONSEP DAN KARAKTER KONSTRUKTIVIS \\ Menurut Sanjaya

mengemukakan "Pemahaman konsep adalah kemampuan siswa yang berupa penguasaan sejumlah materi pelajaran, tetapi mampu mengungkapkan kembali dalam bentuk lain yang mudah dimengerti, memberikan interprestasi data dan mampu mengaplikasi konsep yang sesuai dengan struktur kognitif yang dimilikinya, indikator pemahaman konsep diantaranya: a) mampu menerangkan secara verbal mengenai apa yang telah 
dicapainya, b) mampu menyajikan situasi matematika kedalam berbagai cara serta mengetahui perbedaan, c) mampu mengklasifikasikan objek-objek berdasarkan dipenuhi atau tidaknya persyaratan yang membentuk konsep tersebut, d) mampu menerapkan hubungan antara konsep dan prosedur, e) mampu menberikan contoh dan kontra dari konsep yang dipelajari; 1) mampu menerapkan konsep secara algoritma, 2) mampu mengembangkan konsep yang telah dipelajari.

Menurut para ahli psikologi pendidikan (Silaban, Bajongga, 2006: 7) tentang teori konstruktivis, mahasiswa dituntut untuk menemukan sendiri yang selanjutnya mentransformasikan informasi kompleks, mengecek informasi baru dengan aturan-aturan lama dan memperbaikinya apabila aturan-aturan lama itu tidak lagi sesuai.

Berdasarkan uraian yang dikemukakan di atas, karakter konstruktivis yang akan menjadi fokus penelitian ini adalah:a) adanya kerjasama, b) belajar dengan bergairah, c) menggunakan berbagai sumber, d) siswa aktif, d) siswa kritis

\section{Matematika Diskrit}

- Abstrak, teoritis, analisis, penalaran, kalkulasi dan membutuhkan pemecahan masalah.

- Banyak kritik cara dosen mengajar yang hanyamenekankan pada penguasaan konsep belaka bukan pemahaman konsep

- pemanfaatansoftware pendukung dalam pembelajaran berbasis $e$ learning belum sepenuhnya optimal dipakai dalam pembelajaran perkuliahan matematika diskrit

- Memahami masalah

- Analisis, identifikasi.

- Menggunakan prasyarat atau non prasyarat

- Memvisualisasi dan mengimplementasi

- Membuat generalisasi

- Aktif mengkonstruksi pengetahuan
-Pemahaman Konsep meningkat -Buku Ajar pembelajaran yang valid, praktis, efektif

-Terbentuknya Karakter konstruktivis

\section{Pengembangan Buku Ajar dengan aplikasi $E d m o d o$ berbasis Progresif PACE}

Belum ada Bahan Ajar yang dikembangkan dengan berbantuan aplikasiedmodo berbasis Progresif PACE

\section{Pembelajaran \\ Bermakna}

Konstruktivis sebagai titik awal pembelajaran Aktif mengkonstruksi 


\section{METODE PENELITIAN}

\section{Tahapan Penelitian}

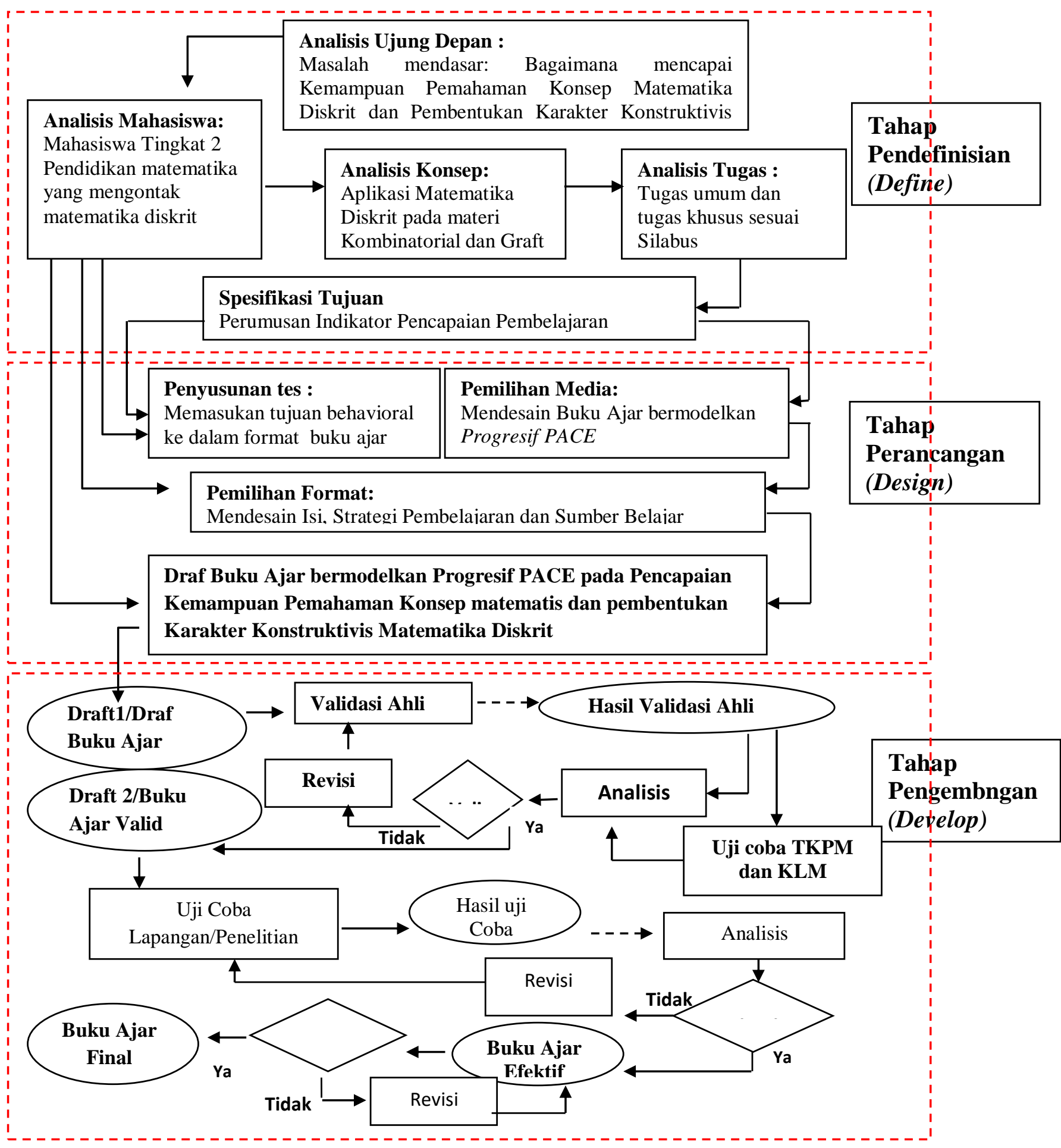

Gambar 2. Tahapan-tahapan Penelitian Pengembangan 
Berikut adalah gambaran secara operasional tahap-tahap Pengembangan bahan ajar yang dikembangan dengan berbasis aplikasi Online education Edmodo dengan model Progresif PACE terhadap pencapaian kemampuan pemahaman konsep dan pembentukan karakter konstruktivis mahasiswa pada kajian mata kuliah matematika diskrit yang mengacu pada Four-D Models yang dimodifikasi hanya sampai tahap develop yang dikemukakan oleh Thiagarajan, Semmel dan Semmel dalam (Hobri, 2010) yaitu define, design,develop and deseeminate.

\section{Instrumen Penelitian}

Instrumen penelitian yang akan dikembangkan meliputi Buku Ajar Mahasiswa

Tabel 1. Rancangan Penelitian
, Rencana Pelaksanaan Pembelajaran, Lembar Kerja Mahasiswa, Tes Kemampuan Pemahaman Konsep matematis. Desain instrumen penelitian yang akan dikembangkan dalam rangka memenuhi unsur-unsur pembelajaran dengan pendekatan realistik. Instrumen pengumpulan data adalah alat bantu yang dipilih dan digunakan oleh peneliti dalam pelaksanaan pengumpulan data (Arikunto 2002). Dalam penelitian ini terdiri:Lembar Validasi, Lembar Angket Respon Siswa, Lembar Pengamatan Pengelolaan Pembelajaran ,Tes KemampuanPemahaman Konsep matematika dan Lembar Validasi Lembar Pengamatan Karakter Konstruktivis

matematika diskrit. Bahan ajar beserta instrument evaluasi (tes) kemudian divalidasi

\begin{tabular}{llll}
\hline & Define & Design & Develop \\
\hline Pengumpulan & & - Menyusun Buku Ajar & - Buku Ajar \\
data & & - Menyusun Tes & - Hasil Tes Penalaran matematis \\
& & Pemahaman konsep & - Hasil Angket Respon mahasiswa \\
& & Matematis & - Hasil Lembar Pengamatan Dosen \\
& & - Menyusun Instrumen & - Hasil Lembar Pengamatan Karakter \\
& & Penelitian & Konstruktivis \\
\hline Analsis Data & Menentukan & Rancangan awal Bahan & Uji Validitas \\
& Spesifikasi & Ajar & Uji Efektifitas \\
& tujuan & & Uji Praktis
\end{tabular}

Penelitian bertujuan untuk menghasilkan bahan ajar efektif, bahan ajar praktis dan valid yang dikembangan dengan berbantuan aplikasi Education Edmodo dengan model Progresif PACE terhadap pencapaian kemampuan pemahaman konsep dan pembentukan karakter konstruktivis mahasiswapada kajian mata kuliah matematika diskrit.Penelitian ini dapat digolongkan dalam jenis penelitian pengembangan, hal ini sesuai dengan tujuan penelitian yang telah dikemukakan sebelumnya. Adapun yang akan dikembangkan dalam penelitian ini adalah buku ajar yang dikembangan dengan berbasis aplikasi Online Education Edmodo dengan model E-learning PACE terhadap pencapaian kemampuan pemahaman konsep dan pembentukan karakter konstruktivis mahasiswapada kajian mata kuliah oleh validator (praktisi dan ahli di lingkungan pendidikan matematika perguruan tinggi, sebagai bahan revisi untuk diteruskan pada ujipraktis pada sembarang mahasiswa tingkat 2 .

\section{HASIL DAN PEMBAHASAN Hasil Pengembangan Perangkat Pembelajaran}

\section{Tahap Pengembangan (Develop)}

Tahap ini adalah untuk menghasilkan draf buku ajar matematika diskrit bermodelkan progresif PACE berbantuan aplikasi Edmodo yang telah direvisi berdasarkan masukan para ahli dan data yang diperoleh dari hasil uji coba. Kegiatan yang dilakukan pada tahap ini terdiri dari dua kegiatan yang dilakukan secara berturut-turut, yaitu; (1) validasi ahli yang meliputi validasi isi dan validasi konstruk; (2) uji coba 
perangkat pembelajaran dan tes kemampuan pemahaman konsep, dipergunakan untuk merevisi draf II menjadi draf final. Uraian singkat dari masing-masing kegiatan pada tahap ini adalah sebagai berikut.

\section{Hasil Penilaian Para Ahli}

Penilaian ahli meliputi semua perangkat pembelajaran matematika dengan menggunakan model progresif PACE dan tes kemampuan pemahaman konsep matematika yang telah disusun pada tahap perancangan. Penilaian ahli dilakukan terhadap draf I dengan berpedoman pada lembar penilaian validator yang dibuat oleh peneliti. Penilaian ini dimaksudkan untuk melakukan validasi terhadap perangkat yang dibuat pada perancangan awal yaitu berupa draf I. Para ahli yang melakukan validasi ini disebut validator, validator yang membantu peneliti dalam melakukan validasi dapat dilihat pada lampiran D.1.

Berdasarkan hasil validasi ahli terhadap perangkat pembelajaran diperoleh hasil berupa saran perbaikan sebagai berikut.

1) Validasi terhadap Buku Ajar Mahasiswa (BAM)

Penilaian validator terhadap BAM didasarkan pada indikator-indikator yang termuat dalam Lembar Validasi BAM (Lihat Lampiran B.3). Dalam penelitian ini skor rata-rata penilaian validator terhadap draf I BAM $=3,63$ (dari skor tertinggi 4) yang berarti termasuk dalam kategori "baik", sedangkan simpulan yang diberikan adalah "dapat digunakan meskipun masih ada sedikit revisi”.

Tabel 2.

\section{Revisi Buku Ajar Mahasiswa}

Hasil Validasi Buku Ajar Mahasiswa

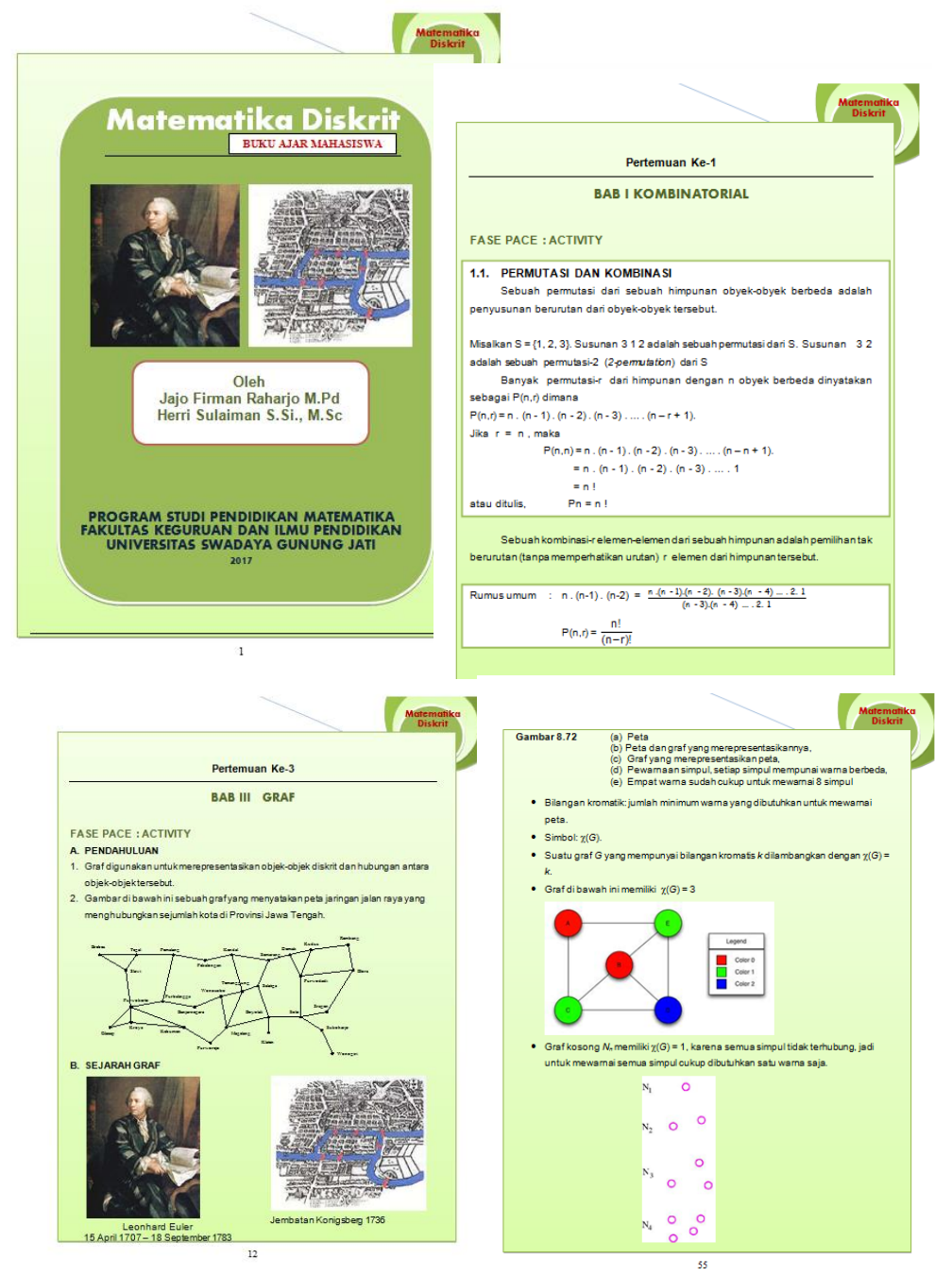

No. Bagian yang $\mathrm{d}$

Catatan revisi

1. materi Tidak semua Materi sedapat materi menyediakan fasilitas pemahaman konsep

2. materi
Sintak progresif mungkin menyediakan fasilitas kemampuan pemahaman konsep Sintak model progresif PACE PACE belum tertulis secara eksplisit

3. materi Belum banyak Seoptimal materi kontekstual yang sudah tertulis secara eksplisit

3.

\begin{tabular}{|c|c|c|c|}
\hline & & $\begin{array}{l}\text { yang } \\
\text { tercantum }\end{array}$ & $\begin{array}{l}\text { materi } \\
\text { kontekstual }\end{array}$ \\
\hline 4. & $\begin{array}{l}\text { Materi } \\
\text { latihan }\end{array}$ & $\begin{array}{lr}\text { Kurang } & \text { soal } \\
\text { latihan } & \text { dan } \\
\text { contoh } & \end{array}$ & $\begin{array}{l}\text { Ditambahkan } \\
\text { contoh dan } \\
\text { latihan, sebelum } \\
\text { latihan } \\
\text { didiskusikan }\end{array}$ \\
\hline 5. & $\begin{array}{l}\text { Ringka } \\
\text { san } \\
\text { materi }\end{array}$ & $\begin{array}{l}\text { Ringkasan } \\
\text { materi berupa } \\
\text { rekreasi } \\
\text { matematika }\end{array}$ & $\begin{array}{l}\text { Dimunculkan } \\
\text { rekreasi } \\
\text { matematika. }\end{array}$ \\
\hline
\end{tabular}




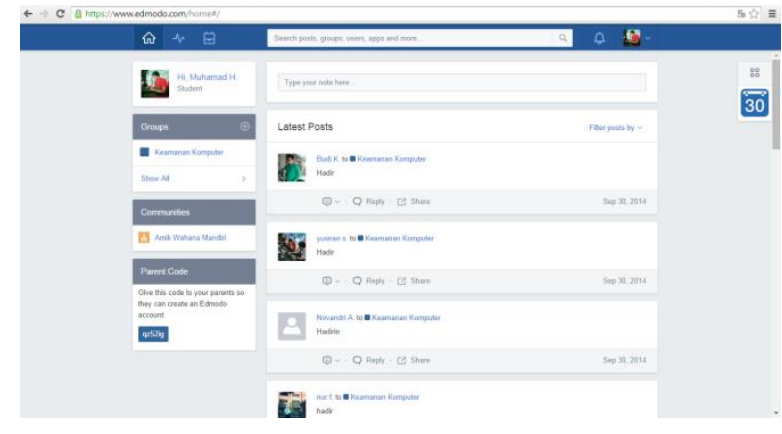

2) Tes Kemampuan Pemahaman Konsep (TKPK)

Pada pengembangan perangkat TKPK, peneliti melakukan proses validasi isi tetapi tidak melakukan penilaian oleh validator (ahli), namun hanya berkonsultasi dengan ahli dan menganalisis butir soal melalui uji

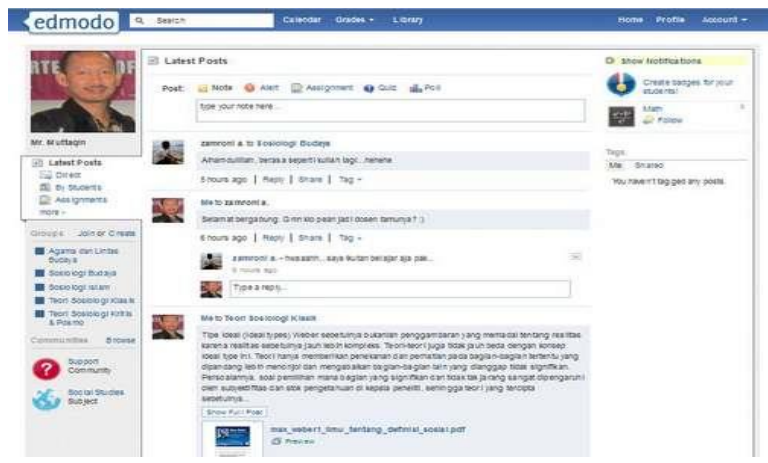

validitas, reliabelitas, tingkat kesukaran dan daya pembeda dari instrumen soal TKPK draf I. Berdasarkan data uji coba ditingkat 2 tes kemampuan pemehaman konsep matematis, dilakukan uji validitas, reliabelitas, tingkat kesukaran dan daya pembeda soal untuk mengetahui kelayakan soal. Hasil yang diperoleh sebagai berikut:

\section{Tabel 3.}

Kesimpulan Hasil Analisis Uji Coba Tes Kemampua Komuikasi Matematika

\begin{tabular}{c|c|c|c|c} 
No. & Vali-ditas & Daya Beda & Kriteria Soal & Kete-rangan Soal \\
\hline 1. & Valid & Signifikan & Mudah & Dipakai \\
\hline 2. & Tidak Valid & Signifikan & Sukar & Dibuang \\
\hline 3. & Valid & Signifikan & Sedang & Dipakai \\
\hline 4. & Tidak Valid & Tidak Signifikan & Sukar & Dibuang \\
\hline 5. & Valid & Signifikan & Sedang & Dipakai \\
\hline 6. & Valid & Signifikan & Sedang & Dipakai \\
\hline 7. & Valid & Signifikan & Sedang & Dipakai \\
\hline 8. & Valid & Signifikan & Sedang & Dipakai \\
\hline 9. & Valid & Tidak Signifikan & sedang & Dibuang \\
\hline 10. & Valid & Signifikan & Mudah & Dipakai
\end{tabular}

Uji Efektifitas Pembelajaran dengan terhadap Kemampuan Pemahaman Konsep. Menggunakan Model Progresif PACE a. Uji Ketuntasan Hasil Tes Kemampuan (Project, Activity, Cooperative and Exercise) Pemahaman Konsep (TKPK)

Tabel 4.

\section{Hasil Analisis Uji Ketuntasan TKPK}

One-Sample Test

\begin{tabular}{|c|c|c|c|c|c|c|}
\hline & \multicolumn{6}{|c|}{ Test Value $=65$} \\
\hline & \multirow[b]{2}{*}{$\mathrm{t}$} & \multirow[b]{2}{*}{$\mathrm{df}$} & \multirow{2}{*}{$\begin{array}{l}\text { Sig. }(2- \\
\text { tailed) }\end{array}$} & \multirow{2}{*}{$\begin{array}{c}\text { Mean } \\
\text { Difference }\end{array}$} & \multicolumn{2}{|c|}{$\begin{array}{l}95 \% \text { Confidence Interval of } \\
\text { the Difference }\end{array}$} \\
\hline & & & & & Lower & Upper \\
\hline Eks & 4.846 & 27 & .000 & 7.864 & 4.55 & 11.15 \\
\hline
\end{tabular}

Karena nilai sig $=0.000<5 \%$, maka Ho ditolak. Artinya rata-rata nilai TKPK tidak sama dengan 65. Selanjutnya untuk mengetahui bahwa nilai rata-rata ketuntasan kelas eksperimen lebih dari 65 dilihat dari tabel di bawah ini. 
Tabel 5. One Sample Statistics One-Sample Statistics

\begin{tabular}{l|c|c|c|c}
\hline & $\mathrm{N}$ & Mean & $\begin{array}{c}\text { Std. } \\
\text { Deviation }\end{array}$ & $\begin{array}{c}\text { Std. Error } \\
\text { Mean }\end{array}$ \\
\hline $\begin{array}{l}\text { Eksperi } \\
\text { men }\end{array}$ & 28 & 72.86 & 10.006 & 1.622
\end{tabular}

Berdasarkan data pada Tabel 5, dapat dilihat bahwa nilai mean $=72,86$, maka nilai rata-rata ketuntasan hasil TKPK lebih dari 65. Output uji ketuntasan klasikal (uji one sample t-test) secara lengkap dapat dilihat pada tabel. lampiran. Ketuntasan kemampuan pemahaman konsep yang diukur adalah ketuntasan secara klasikal. Telah dinyatakan bahwa dalam uji ketuntasan klasikal menghasilkan bahwa nilai rata-rata ketuntasan belajar dikelas eksperimen lebih dari 65 .

\section{b. Uji Perbedaan Hasil TKPK Kelas Eksperimen dengan Kelas kontrol}

Dalam penelitian ini analisis data uji perbedaan hasil TKBA kelas eksperimen dengan kelas kontrol diuji dengan menggunakan Independent Sample Test dan diperoleh hasil yang dapat dilihat

Tabel 6.

Hasil Perbedaan Hasil TKPK dengan Independent Sample Test Independent Samples Test

\begin{tabular}{|c|c|c|c|c|c|c|c|c|c|c|}
\hline \multicolumn{4}{|c|}{$\begin{array}{c}\text { Levene's Test for Equality of } \\
\text { Variances }\end{array}$} & \multicolumn{7}{|c|}{ t-test for Equality of Means } \\
\hline & & \multirow[t]{2}{*}{$\mathrm{F}$} & \multirow[t]{2}{*}{ Sig. } & \multirow[t]{2}{*}{$\mathrm{t}$} & \multirow[t]{2}{*}{ df } & \multirow[t]{2}{*}{$\begin{array}{l}\text { Sig. }(2- \\
\text { tailed) }\end{array}$} & \multirow[t]{2}{*}{$\begin{array}{c}\text { Mean } \\
\text { Difference }\end{array}$} & \multirow[t]{2}{*}{$\begin{array}{l}\text { Std. Error } \\
\text { Difference }\end{array}$} & \multicolumn{2}{|c|}{$\begin{array}{l}95 \% \text { Confidence } \\
\text { Interval of the } \\
\text { Difference }\end{array}$} \\
\hline & & & & & & & & & Lower & Upper \\
\hline \multirow[t]{2}{*}{ TKPK } & $\begin{array}{l}\text { Equal variances } \\
\text { assumed }\end{array}$ & 1.366 & .242 & 7.562 & 74 & .000 & 16.522 & 2.181 & 12.171 & 20.876 \\
\hline & $\begin{array}{l}\text { Equal variances } \\
\text { not assumed }\end{array}$ & & & 7.5642 & 73.192 & .000 & 16.522 & 2.181 & 12.171 & 20.877 \\
\hline
\end{tabular}

Berdasarkan Tabel 5 diatas dapat diperoleh simpulan bahwa dilihat dari nilai kesamaan dua varians diperoleh $\mathrm{F}=1,366$ dan $\operatorname{sig}=0,242=24,2 \%$ (lebih dari $5 \%$ ). Ini berarti Ho diterima, artinya kedua sampel mempunyai varian yang sama. Selanjutnya dipilih Equal varians assumed, diperoleh sig . (2-tailed) $=0.000=0 \%<5 \%$. Ini berarti Ho ditolak.Artinya kedua populasi mempunyai nilai rata-rata hasil TKPK yang berbeda.Untuk menentukan kelas mana yang mempunyai nilai rata-rata lebih tinggi digunakan analisis Group Statistics yang dilihat pada table.

\section{Tabel 7}

Group Statistics

\begin{tabular}{|l|l|l|l|l|l|}
\hline \multicolumn{6}{|c|}{ Group Statistics } \\
& Kelas & $\mathrm{N}$ & Mean & $\begin{array}{l}\text { Std. } \\
\text { Deviation }\end{array}$ & $\begin{array}{l}\text { Std. Error } \\
\text { Mean }\end{array}$ \\
\hline TKPK & 1 & 38 & 72.85 & 10.007 & 1.622 \\
\hline & 2 & 38 & 56.32 & 9.006 & 1.459 \\
\hline
\end{tabular}

Dari tabel di atas menunjukan bahwa nilai rata-rata hasil TKPK kelas eksperimen lebih tinggi dibandingkan kelas kontrol. Output uji perbedaan hasil TKPK. Dari hasil TKPK dengan uji statistik yaitu uji ketuntasan hasil TKPK dan uji perbedaan hasil TKPK kelas eksperimen dengan kelas kontrol dapat disimpulkan bahwa Ketuntasan pembelajaran menggunakan model progresif PACEdalam mengembangkan kemampuan pemahaman konsep matematika diskrit. 
PENGARUH PENGGUNAAN BUKU AJAR YANG DIKEMBANGKAN DENGAN PEMBELAJARAN DENGAN MODEL PROGRESIF PACE TERHADAP PEMBENTUKAN KARAKTER KONSTRUKTIVIS MAHASISWA

\section{a. Analisis Karakter Konstruktivis Mahasiswa}

Berdasarkan hasil observasi terdapat peningkatan keaktivan dalam pembentukan karakter konstruktivis mahasiswa dari pertemuan awal hingga pertemuan akhir, berikut penulis sajikan dalam bentuk diagram batang pada gambar di bawah ini.

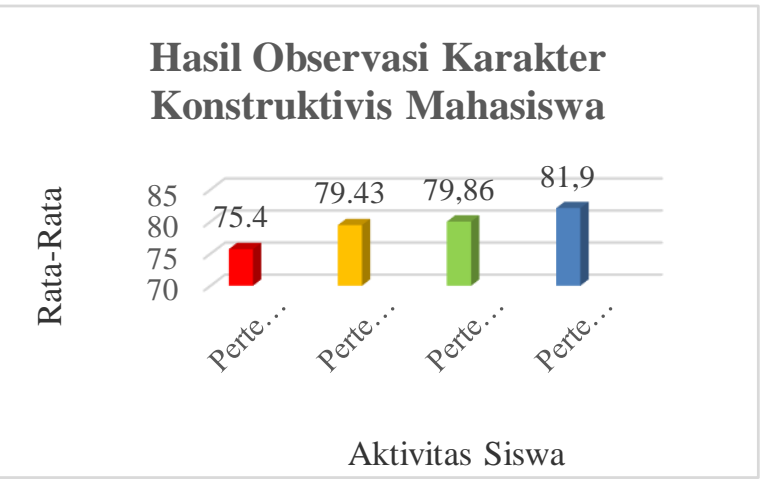

Gambar 3. Hasil Obeservasi Kontruktivisme Mahasiswa

Berdasarkan diagram batang di atas, dapat dilihat bahwa terdapat peningkatan dalam membentuk karakter kontruktivis mahasiswa dari pertemuan pertama hingga pertemuan terakhir. Pada pertemuan awal, rata-rata skor aktivitas siswa masih di bawah 80 , yaitu 75,4 . Hal ini disebabkan karena mahasiswa masih belum terbiasa dengan model progresif PACEsehingga hanya sebagian kecil mahasiswa yang dapat mengikuti pembelajaran dengan baik dan sesuai dengan penilaian aktivitas siswa.Namun, pertemuan berikutnya hingga pertemuan akhir, aktivitas mahasiswa sudah mulai ada peningkatan dan sudah mencakup kedalam kriteria penilaian aktivitas karakter konstruktivis yang digunakan observer.
UJI KEPRAKTISAN PEMBELAJARAN DENGAN MENGGUNAKAN MODEL PROGRESIF PACE

\section{a. Analisis Respon Mahasiswa terhadap Pembelajaran}

Data hasil skala kemandirian belajar mahasiswa setelah dilakukan pembelajaran dengan menggunakan model progresif $P A C E$ akan disajikan dalam bentuk diagram batang di bawah ini.
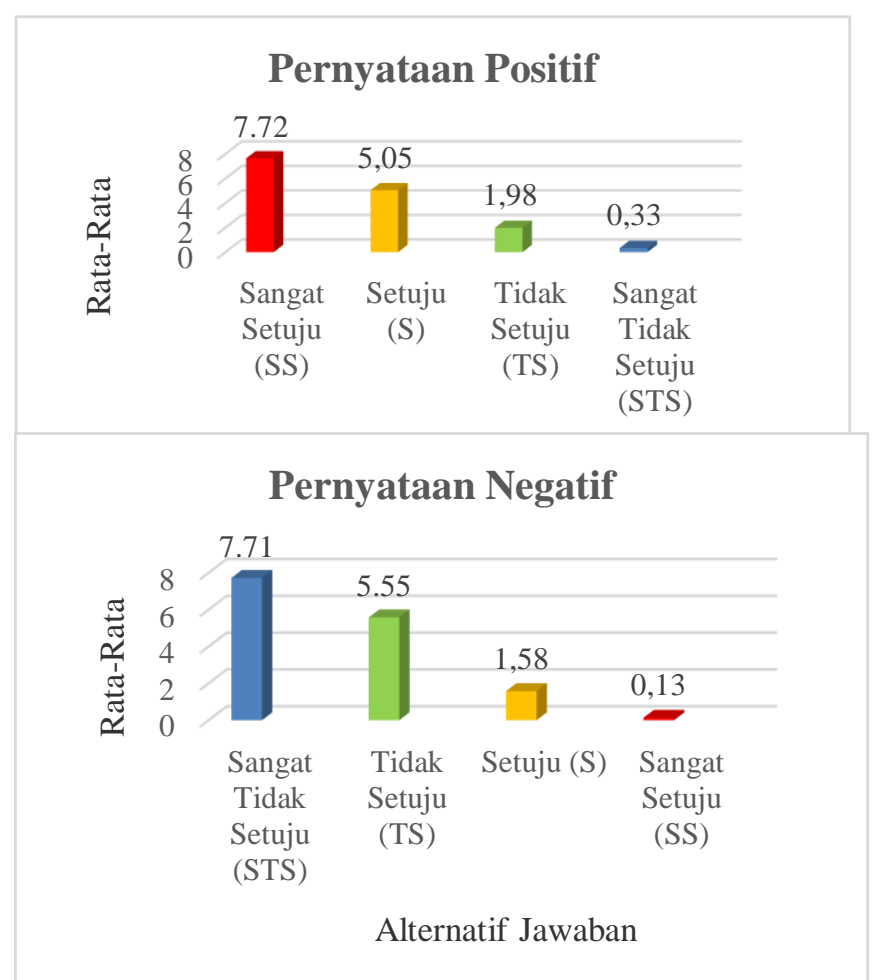

\section{Gambar 4. Rekapitulasi Data untuk Pernyataan Positif dan Negatif}

Berdasarkan rekapitulasi data skala kemandirian belajar siswa, pada gambar yang pertama hampir seluruh siswa menjawab sangat setuju untuk pernyataan yang bersifat positif, hal ini bisa dilihat pada Gambar pernyataan positif dengan rata-rata untuk alternatif jawaban Sangat Setuju (SS) 7,71, Setuju (S) 5,55, Tidak Setuju (TS) 1,58, dan Sangat Tidak Setuju (STS) 0,13. Sedangkan pada gambar yang kedua, hampir seluruh siswa menjawab sangat tidak setuju untuk pernyataan yang bersifat negatif, hal ini bisa dilihat pada Gambar pernyataan negative 
dengan rata-rata untuk alternatif jawaban Sangat Tidak Setuju (STS) 7,73, Tidak Setuju (TS) 5,58, Setuju (S) 1,58, dan Sangat Setuju (SS) 0,13 .

Hasil analisis respon positif mahasiswa yang diperoleh dari pemberian kuisioner/angket dianalisis dengan menentukan banyaknya mahasiswa yang memberi jawaban bernilai respon positif dan negatif untuk setiap kategori yang ditanyakan dalam angket memberikan hasil lebih dari 85\% dari banyaknya subjek yang diteliti memberi respon positif. Hal ini menunjukan bahwa pembelajaran dengan menggunakan model Progresif PACE dan dengan perangkat pembelajarannya memberikan respon positif.

Kepraktisan Buku Ajar dilihat Pengelolaan Pembelajaran yang dilakukan Dosen

Kepraktisan Perangkat dilihat dari Respon Positif siswa dan Kepraktisan Perangkat dilihat Pengelolaan Pembelajaran yang dilakukan Guru (Hobri, 2010: 151).Perangkat suatu pembelajaran dikatakan praktis apabila memenuhi kriteria penilaian baik dari respon mahasiswa dan hasil observasi pengamatan pengelolaan pembelajaran dosen.

Hasil analisis pengamatan pengelolaan pembelajaran yang dilakukan dosen yang diperoleh dari mengamati atau mengukur kemampuan dosen dalam mengelola pembelajaran dan dari hasil pengembangan berdasarkan tahapan-tahapan (Sintaks) model Progresif PACE memberikan hasil bahwa tingkat kemampuan dosen mengelola pembelajaran adalah baik. Hal ini dilihat dari kriteria TKD (Tingkat Kemampuan Dosen) yang memberikan rata-rata 4,30 (dari rata-rata maksimal 5). Hasil uji kepraktisan dapat dilihat pada Lampiran C.16. Sehingga perangkat memenuhi kepraktisan.

\section{PEMBAHASAN PRODUK AKHIR}

Berdasarkan hasil penelitian di atas, dapat dijabarkan pembahasan hasil penelitian yang dibagi dalam dua kelompok yaitu pembahasan hasil pengembangan perangkat dan pembahasan hasil uji coba perangkat (eksperimen).

Pembahasan Hasil Pengembangan Buku Ajar

Seperti telah dijelaskan sebelumnya bahwa perangkat yang dikembangkan pada penelitian ini ada 2 yaitu : (1) Buku Ajar Siswa, (2) TKPK (Tes Kemampuan Pemahaman Konsep). Proses pengembangan perangkat dimulai dengan menyusun draf awal (draf I). Draf I perangkat divalidasi oleh 4 orang yang kompeten untuk menilai kelayakan perangkat pembelajaran dan dilakukan revisi-revisi sesuai dengan masukan validator sehingga diperoleh Draf II.Perangkat Draf II tersebut selanjutnya diuji cobakan. Selama proses uji coba, dilakukan revisi-revisi perangkat sesuai dengan tuntutan lapangan atau masukan-masukan pihak luar sehingga diperoleh draf akhir (Draf III). Pembahasan hasil pengembangan perangkat untuk masingmasing perangkat dapat dijelaskan sebagai berikut.

\section{Buku Ajar Mahasiswa}

Buku Ajar Siswa dengan menggunakan model Progresif PACE merupakan buku pegangan mahasiswa dan sebagai tugas-tugas terstruktur mahasiswa yang akan dibahas pada kegiatan pembelajaran yang didalamnya mencakup petunjuk, pengajuan masalah konkret sabagai bahan pembelajaran dan masalah-masalah sebagai batu loncatan untuk melakukan investigasi. Buku ajar mahasiswa diharapkan mampu memberikan kontribusi membawa pebelajaran ke arah yang lebih efektif dan progresif. 
Berdasarkan hasil validasi keempat validator dengan langkah-langkah yang telah ditempuh dinyatakan buku ajar mahasiswa matematika diskrit valid dengan rata-rata untuk perangkat Buku Siswa adalah 3, 63 dan termasuk dalam kriteria sangat baik. Ada beberapa validator yang menyatakan buku siswa dalam kategori baik dan dapat digunakan dengan sedikit revisi. Hasil revisi (Draf 2) terdapat pada lampiran.

Revisi terhadap Buku ajar mahasiswa meliputi penambahan masalah yang kontekstual sebagai bahan pembelajaran dalam melakukan investigasi, kegiatan eksplorasi, elaborasi dan konfirmasi harus dijabarkan secara eksplisit dalam kegiatan pembelajarannya di BAM. Pengembangan buku ajar mahasiswa dilakukan untuk membantu keberhasilan pembelajaran yang diharapkan menghasilkan pembelajaran yang berpusat pada mahasiswa yang menekankan pada pembentukan karakter konstruktivis mahasiswa untuk menggali informasi dari berbagai sumber belajar. Media yang dipilih dalam pengembangan buku ajar ini adalah berbantuan aplikasi education Edmodo, yang dalam hal ini dapat mendorong mahasiswa lebih antusias, progresif dan efektif di segala kondisi dan situasi. Project yang dikembangan dalam model pembelajaran PACE yang pembelajarannya menggunakan aplikasi edmodo sangat efektif dalam mengkonstruksi pemahaman konsep mahasiswa secara mandiri maupun cooperative sehingga tercipta suasana belajar yang komprehensif dimana pembelajaran tidak hanya dibatasi pada ruang kelas saja tapi disegala waktu dan tempat. Dalam hal ini sumber belajar seperti buku mahasiswa sangat penting sebagai sumber informasi bagi mahasiswa apalagi dalam hal mencapai kemampuan pemahaman konsep matematika diskrit yang meliputi kombinatorial, graft dan tree.

\section{Tes Kemampuan Pemahaman Konsep Matematis}

Dalam Depdiknas (2008), menyatakan bahwa tes yang baik harus memenuhi setidaknya dua karakteristik, yaitu : validitas dan reliabelitas. Validitas artinya ketepatan interpretasi hasil prosedur pengukuran, reliabel artinya konsistensi hasil prosedur pengukuran. Sedangkan Messick (dalam Depdiknas 2008 : 4) menjelaskan bahwa validitas tes merupakan suatu intergrasi pertimbangan evaluasi derajat keterangan empiris yang mendasarkan pemikiran teoritis yang mendukung ketepatan dan kesimpulan berdasarkan pada skor tes.

Syarat soal yang bermutu adalah bahwa soal harus sahih (valid), dan handal. Sahih maksudnya bahwa setiap alat ukur hanya mengukur satu dimensi/aspek saja. Handal maksudnya bahwa setiap alat ukur harus bisa memberikan hasil pengukuran yang tepat, cermat dan ajeg (reliabel). Dalam penelitian ini pengembangan perangkat TKPK menghasilkan instrumen soal yang baik, yaitu instrumen soal yang memenuhi kriteria valid, reliabel, tingkat kesukaran dan mempunyai daya pembeda yang positif.

Analisis dilakukan melalui uji validitas, reliabilitas, tingkat kesukaran dan daya pembeda pada butir soal yang dikembangkan. Berpatokan pada kriteria yang telah ditetapkan selanjutnya dipilih instrumen soal yang akan dijadikan produk akhir TKPK. Jadi produk akhir TKPK adalah seperangkat soal yang memenuhi kriteria valid, reliabel, tingkat kesukaran dan daya pembeda seperti yang telah ditetapkan diatas

Berdasarkan kriteria yang telah ditetapkan maka dipilih butir-butir soal yang akan dijadikan produk akhir TKPK. Butir soal yang dipilih adalah soal yang memenuhi 4 kritria berikut : 
a. Berdasarkan hasil perhitungan validasi butir soal, maka soal TKPK yang digunakan adalah instrumen yang memenuhi kriteria valid, yaitu yang mempunyai nilai korelasi Product Moment $\left(\mathrm{r}_{\mathrm{xy}}\right)$ dengan validitas tinggi. Hasil dari uji validitas butir soal dengan korelasi Product Moment, dari 10 soal diperoleh 8 soal valid dengan kriteria tingkat validitas tinggi dan sangat tinggi.

b. Berdasarkan hasil perhitungan Reliabilitas butir soal, maka soal TKPK yang digunakan adalah instrumen yang memenuhi kriteria reliabel. Dari uji coba reliabilitas 10 butir soal diperoleh hasil $\mathrm{r}_{11}=0$, 916. Berdasarkan kriteria yang terdapat pada Bab III maka soal TKKM reliabel.

c. Memuat butir soal yang memenuhi tingkat kesukaran mudah, sedang dan sukar. Berdasarkan kriteria pada bab III, maka soal 1 dan 10 dalam kategori mudah, soal 3,5, 6,7,8 dan 9 dalam kategori sedang dan soal 2 dan 10 dalam kategori sukar.

d. Daya pembeda dari 10 butir soal menunjukan soal 4 dan soal 9 mempunyai daya pembeda yang tidak signifikan, selain itu daya pembeda dinyatakan signifikan artinya butir soal mempunyai kemampuan membedakan antar siswa dengan kemampuan baik dan siswa dengan kemampuan kurang baik.

\section{Pembahasan Hasil Uji Coba Perangkat Pembelajaran}

Setelah semua perangkat pembelajaran direvisi (draf II) sesuai dengan saran validator, selanjutnya dilakukan uji coba lapangan untuk memperoleh masukan-masukan guna merevisi perangkat pembelajaran draf II menjadi draf III. Langkah selanjutnya adalah uji normalitas dan uji homogenitas. Data yang diuji adalah data nilai ulangan semester I mahasiswa kelas eksperimen dan kelas kontrol. Berdasarkan hasil pengujian homogenitas dan normalitas dapat dikatakan bahwa kelas eksperimen dan kelas kontrol adalah kelas yang homogen dan berdistribusi normal. Sehingga, dapat disimpulkan bahwa pengambilan sampel secara acak dapat dibenarkan.

Pelaksanaan penelitian ini diberikan dalam 4 pertemuan untuk pembelajaran pada kelas eksperimen yang dikenai model Progresif PACE untuk mencapai kemampuan pemahaman konsep matematika dan 1 kali pertemuan untuk tes kemampuan pemahaman matematika pada kelas eksperimen dan kelas kontrol. Pembelajaran diampu oleh kolaborasi peneliti dengan guru. Selanjutnya perangkat diuji cobakan pada kelas eksperimen. Hasil dari uji coba perangkat terdiri dari data hasil TKPK di kelas eksperimen dan data hasil TKPK di kelas kontrol, data hasil respon positif mahasiswa terhadap pembelajaran dan data hasil pengamatan pengelolaan pembelajaran yang dilakukan oleh dosen. Data-data tersebut selanjutnya dianalisis untuk diketahui ketuntasannya, kemampuan membedakan antara kelas eksperimen dan kelas kontrol dan kepraktisannya. Pembahasan hasil uji coba perangkat itu dapat dijelaskan sebagai berikut.

\section{Ketuntasan Kemampuan Pemahaman \\ Konsep Matematika}

Ketuntasan kemampuan pemahaman konsep matematika yang diukur adalah ketuntasan secara klasikal. Telah dinyatakan bahwa dalam uji ketuntasan klasikal menghasilkan bahwa nilai rata-rata ketuntasan belajar dikelas eksperimen lebih dari 65. Hal ini menunjukan secara nyata keberhasilan proses pembelajaran menggunakan model Progresif PACE dan pengembangan buku ajarnya. Keberhasilan ini disebabkan karena model Progresif PACE dan buku ajar yang 
dikembangkan berhasil mencapai kemampuan pemahaman konsep matematika.

Model Progresif PACE memberi kesempatan lebih luas pada mahasiswa untuk belajar yang dimulai dengan project, activity, cooperative and exercise dalam memecahkan suatu permasalahan,sebagai batu loncatan dalam melakukan investigasi kelompok maupun individu sehingga keefektifan diskusi terjalin sampai ditemukannya solusi. Kemudian pemahaman konsep menuntut mahasiswa secara aktif dapat mempresentasikan hasil penemuan masalahnya atau pemecahan masalahnya untuk dimengerti dan dipahami melalui mengkonstruksi pengetahuan secara mandiri. Dari hasil ini membuktika bahwa pembelajaran dengan menggunakan buku ajar yang dikembangkan dengan model Progresif PACE berbantuan aplikasi Education Edmodo dapat menuntaskan kemampuan pemahaman konsep matematika.

\section{Perbedaan Kelas Eksperimen dengan Kelas Kontrol}

Berdasarkan hasil membandingkan nilai rata-rata kelas eksperimen dan kelas kontrol dapat disimpulkan bahwa kelas eksperimen mempunyai nilai rata-rata ketuntasan lebih tinggi dibandingakan nilai rata-rata ketuntasan kelas kontrol. Ini menunjukan pembelajaran menggunakan model Progresif PACE berbantuan Education Edmodo yang lebih menekankan pada pencapaian pemahaman konsep matematika efektif. Sedangkan pengembangan buku ajar matematika diskrit dan pembelajaran membantu mahasiswa dapat lebih banyak lagi menggali informasi-informasi yang berasal dari banyak sumber.

Pengembangan perangkat dan pembelajaran menggunakan model Progresif PACE berbantuan Education Edmodo menghasilkan proses belajar berlangsung sangat optimal. Pengembangan buku ajar matematika diskrit dan pembelajaran yang dilakukan pada kelas ekperimen mempunyai kecenderungan keterkaitan yang lebih kuat dibandingkan pembelajaran pada kelas kontrol.

\section{Kepraktisan Perangkat dilihat dari Respon} Positif Mahasiswa dan pengelolaan Pembelajaran yang dilakukan Dosen.

1)Kepraktisan Perangkat dilihat dari Respon Positif Mahasiswa

Hasil analisis respon positif mahasiswa yang diperoleh dari pemberian kuisioner/angket dianalisis dengan menentukan banyaknya mahasiswa yang memberi jawaban bernilai respon positif dan negatif untuk setiap kategori yang ditanyakan dalam angket memberikan hasil lebih dari $80 \%$ dari banyaknya subjek yang diteliti memberi respon positif. Hal ini menunjukan bahwa pembelajaran dengan menggunakan model Progresif PACE berbantuan Education Edmodo dan dengan buku ajar yang dikembangkan pembelajarannya memberikan respon positif. Artinya pembelajaran yang dimulai dari memahami masalah ataupun mengkonstruksi pemahaman untuk menemukan solusi pemecahan masalahnya dapat menumbuhkan kemandirian mahasiswa dalam upaya menemukan cara memecahkan masalah. Ini berarti pembelajaran telah menerapkan teori Vygotsky tentang Scaffolding yaitu upaya menemukan sendiri cara memecahkan masalah sehingga memungkinkan mahasiswa tumbuh mandiri.

Melalui pembelajaran menggunakan pembelajaran matematika dengan model Progresif PACE berbantuan Education Edmodo juga membantu mahasiswa dalam mencapai karakter konstruktivis. Setelah mahasiswa menemukan cara memecahkan masalah, Progresif PACE berbantuan Education Edmodo menuntut mahasiswa 
dapat mempresentasikan hasil secara langsung baik lisan maupun tulisan dan memaparkan ide yang ditemui ke dalam model matematika. Dick dan Carey (dalam Uno, 2009:6) menyatakan bahwa proses pembelajaran akan lebih berhasil apabila siswa melakukan latihan secara langsung dan relevan dengan tujuan pembelajaran.

Pembelajaran dikatakan praktis apabila terdapat respon positif siswa (mahasiswa) terhadap pembelajaran dan pengelolaan pembelajaran yang dilakukan pengajar (dosen) adalah baik (dalam Hobri, 2010 : 27). Dari pembahasan di atas maka pembelajaran dengan model Progresif PACE berbantuan Education Edmodo dan pengembangan buku ajar pembelajarannya praktis untuk mencapai kemampuan pemahaman konsep matematika.

2)Kepraktisan Perangkat dilihat Pengelolaan Pembelajaran yang dilakukan Dosen

Hasil analisis pengamatan pengelolaan pembelajaran yang dilakukan dosen yang diperoleh dari mengamati atau mengukur kemampuan dosen dalam mengelola pembelajaran dan dari hasil pengembangan berdasarkan tahapan-tahapan (Sintaks) model Progresif PACE berbantuan Education Edmodo memberikan hasil bahwa tingkat kemampuan dosen mengelola pembelajaran adalah baik. Hal ini dilihat dari kriteria TKD (Tingkat Kemampuan Dosen) yang memberikan rata-rata 4,30 (dari rata-rata maksimal 5).

Hobri (2010: 44) mengemukakan bahwa indikator kemampuan pengajar (dosen) mengelola pembelajaran dikatakan baik jika (1) penerapan sintaks pembelajaran sesuai dengan modelnya, (2) pengelolaan waktu yang sesuai, (3) adanya kegiatan penutup yang sesuai dengan esensi atau kesimpulan dari pembelajaran dan dikategorikan baik, dan (4) suasana kelas sangat antusian dan aktif dan dikategorikan baik.
Ketrampilan dosen dalam menerapkan skenario kegiatan pembelajaran sesuai dengan sintaks model Progresif PACE berbantuan Education Edmodo yang telah diuraikan secara operasional. Sumber data kemampuan dosen mengelola pembelajaran dengan menerapkan model Progresif PACE berbantuan Education Edmodo berpedoman pada perangkat-perangkat yang telah dikembangkan yang ditujukan untuk mencapai kemampuan pemahaman konsep matematika.

Dari pembahasan di atas maka pembelajaran dengan model Progresif PACE berbantuan Education Edmodo dan pengembangan buku ajar praktis untuk mencapai kemampuan pemecahan masalah matematika.

Dari komponen-komponen yang dibahas yaitu ketuntasan kemampuan pemahaman konsep matematika, perbedaan kelas eksperimen dengan kelas kontrol dan kepraktisan dilihat dari respon positif mahasiswa dan pengelolaan pembelajaran dosen terbukti bahwa pembelajaran matematika dengan menggunakan perangkat pembelajaran model Progresif PACE berbantuan Education Edmodo pada mata kuliah matematika diskrit memenuhi tiga hal yaitu (1) pembelajaran mencapai ketuntasan untuk mencapai kemampuan pemahaman konsep matematika, (2) Kemampuan pemahaman konsep matematika kelas eksperimen lebih baik dari kelas kontrol dan (3) perangkat pembelajaran yang dikembangkan praktis untuk mencapai kemampuan pemahaman konsep matematika. Jadi berdasarkan hasil dan pembahasan penelitian di atas maka perangkat pembelajaran matematika yang dikembangkan dengan model Progresif PACE berbantuan Education Edmodo untuk mencapai kemampuan pemahaman konsep matematika valid, buku ajar yang 
dikembangkan efektif dan aplikasi buku ajar yang dikembangkan praktis. Sehingga diperoleh pengembangan perangkat pembelajaran yang baik dapat tercapai.

\section{Hasil Penelitian yang Relevan}

Hasil Sudibyo (2013) yang menyatakan bahwa hasil belajar siswa setelah menggunakan Edmodo Blog Education, nilai kognitif siswa cukup meningkat dibandingkan sebelumnya menjadi $76,05 \%$ dengan Penggunaan Media Pembelajaran Fisika dengan ELearning Berbasis Edmodo Blog Education Pada Materi Alat Optik.

\section{DAFTAR RUJUKAN}

Arikunto, S. 2006. Dasar-Dasar Evaluasi Pendidikan (Edisi Revisi). Jakarta: Bumi Aksara.

Depdiknas.2008d. Panduan Penulisan Butir Soal. Jakarta: Departemen Pendidikan Nasional. Dirjen Manajemen Pendidikan Dasar dan Menengah. Direktorat Pembinaan Sekolah Menengah Atas.

Hobri, 2010.Metode Penelitian Pengembangan. Jember:Pena Salsabila.

Lee, Carl. 1999. An Assesment of the PACE Strategi for an Introduction Statistic Course. USA:Central Michigan University.

Nieveen. 2007. Formative Evaluation in Educational Design Research. Dalam An Introduction to Educational Design Research (van den Akker, Bannan, Kelly, Nieveen \& Plomp)

Sanjaya, W. (2009).Strategi Pembelajaran Berorientasi Standar Proses Pendidikan. Jakarta: Prenada Media Group.

Silaban, Bajongga. 2006. Implikasi konstruktivis terhadap Pembelajaran
Kooperatif. Jurnal Darma Agung Vol IX No.01/Januarai/2016.STT Telkom.

Sudibyo, W. 2013.Penggunaan Media Pembelajaran Fisika dengan ELearning Berbasis Edmodo Blog Education Pada Materi Alat Optik untuk meningkatkan Respons Motivasi dan Hasil Belajar Siswa Di SMPN 4 Surabaya.Jurnal Inovasi Pendidikan Fisika Vol. 02 No. 03 Tahun 2013, 187.

Sulthon.2013. Peningkatan Kualitas Pembelajaran Melalui Pendekatan Konstruktivis dalan Pendidikan Bagi anak Usia Dini.Jurnal Vol.1 No.1 julidesember 2013.IKIP Pontianak.

Thiagarajan, S. 1974. Instruksional Development for Training Teachers of Exceptional Student : A Sourcebook. Minneapolis: Indiana University Bloomington.

Uno, B.H. (2008). Model Pembelajaran.Jakarta:Bina Aksara. 